\title{
Metformin attenuates steroidogenesis in ovarian follicles of the broiler breeder hen
}

\author{
Evelyn A Weaver and Ramesh Ramachandran \\ Center for Reproductive Biology and Health, Department of Animal Science, The Pennsylvania State University, \\ University Park, Pennsylvania, USA \\ Correspondence should be addressed to R Ramachandran; Email: RameshR@psu.edu
}

\begin{abstract}
The follicular hierarchy in broiler breeder chicken ovary is often deranged due to excessive ovarian follicular recruitment, resulting in a condition that resembles polycystic ovary syndrome (PCOS) in women. Metformin is widely prescribed to correct PCOS and has been shown to affect granulosa cell functions in humans and rodent models. The objectives of this study are to determine the effects of metformin on signal transduction pathways, gene expression related to steroidogenesis, and progesterone secretion from granulosa cells isolated from the most recently recruited preovulatory and prehierarchical follicles of broiler breeder chickens. Granulosa cells were treated with $0,1,10$, or $20 \mathrm{mM}$ of metformin in the presence of FSH. The abundance of pAMPK, pACC, pERK, and pAkt was determined by Western blotting. The expression of genes related to progesterone biosynthesis was quantified by qPCR. Progesterone concentrations in culture media were quantified by ELISA. Metformin treatment did not have an effect on the abundance of pAMPK and pACC in prehierarchical follicles but significantly decreased the abundance of pERK and pAkt in a dose-dependent manner in preovulatory and prehierarchical follicles. The expression of genes related to steroidogenesis such as FSHR, STAR, CYP11A1, HSD3B, and progesterone secretion was significantly decreased in response to metformin treatment in a dose-dependent manner. Our data suggest that metformin treatment attenuates progesterone secretion via AMPK-independent pathways in granulosa cells of prehierarchical and preovulatory follicles of broiler breeder hens. Further studies are required to determine if metformin administration could ameliorate ovarian dysfunction in obese broiler breeder hens.

Reproduction (2020) $\mathbf{1 6 0} 659-672$
\end{abstract}

\section{Introduction}

In order for the leghorn chicken to produce a sequence (or clutch) of eggs, they must maintain a small cohort of viable, undifferentiated (prehierarchical) follicles. A single prehierarchical follicle is recruited daily from this cohort into the preovulatory pool of follicles and undergoes rapid growth and differentiation prior to ovulation (Johnson 2015). In the leghorn hen, a prolific egg producer ovulating approximately every $25 \mathrm{~h}$ for almost a year, there are few problems with ovarian follicular recruitment, largely due to decades of genetic selection favoring egg production. In contrast, broiler breeder hens, the parent stock of commercial broiler chickens, are genetically selected for faster and efficient body growth in their progenies. As a consequence, broiler breeders have poor reproductive efficiency potentially due to rapid somatic growth and increased adiposity, thus resulting in severe ovarian dysfunction. Full-fed broiler breeder hens display heavier ovaries, excessive follicular recruitment, double ovulation, or increased incidence of ovarian regression (Yu et al. 1992a). The hyper-recruitment of prehierarchical follicles and a deranged preovulatory follicular hierarchy often leads to decreased egg production, lower percentages of fertility and hatchability of eggs, and decreased viability of embryos (Yu et al. 1992a).

Although the exact mechanisms underlying ovarian dysfunction in broiler breeder hens still remain elusive, previous studies have shown this could possibly be related to obesity-induced metabolic dysfunction and lipotoxicity (Cassy et al. 2004, Chen et al. 2006, Walzem \& Chen 2014). Previous studies in which broiler breeder hens were allowed to consume feed ad libitum reported irregular metabolic and steroid hormonal profiles, including increased production of androstenedione by small white follicles, increased plasma levels of androstenedione, decreased levels of estradiol- $17 \beta$ and increased levels of plasma insulin and glucose (Yu et al. 1992b, Chen et al. 2006, Pan et al. 2012). These studies also reported conditions related to metabolic disorder, such as increased plasma concentrations of triglycerides, non-esterified fatty acids, very-low density lipoproteins, ceramide levels, and excessive circulating saturated fatty acids (Chen et al. 2006, Pan et al. 2012). Interestingly, many of the abnormal ovarian and biochemical changes in broiler breeder hens appear to be similar to a condition in women known as polycystic ovary syndrome (PCOS), 
including the biochemical hallmark of increased plasma levels of androgens (Pasquali \& Casimirri 1993). PCOS is most commonly associated with obesity, metabolic syndrome, irregular steroid hormone production, irregular ovulation, and poor fertility, all of which have been previously observed in broiler breeder hens (Pasquali et al. 2003, Walzem \& Chen 2014).

Metformin, a biguanide compound, is commonly prescribed for the treatment of polycystic ovary syndrome and is aimed to correct insulin resistance that is often encountered in women with PCOS. Treatment with metformin has been associated with increased ovulation, fertilization and pregnancy rates (Velazquez et al. 1997, Vandermolen et al. 2001), normalization of the endocrine profile, as well as a return to normal menstrual cyclicity (Morin-Papunen et al. 1998, van Santbrink et al. 2005, Tang et al. 2006) in women with PCOS. These effects have generally been attributed to the systemic antihyperglycemic and insulin-sensitizing effects of metformin (Prager et al. 1986, Perriello et al. 1994), but studies have shown that metformin is able to exert direct effects on the ovary and directly inhibit ovarian steroidogenesis (Ehrmann et al. 1997, Vrbikova et al. 2001, Bertoldo et al. 2014). Previous studies have shown that treatment with metformin decreased the abundance of proteins related to steroidogenesis and decreased secretion of progesterone and estradiol from human, bovine and rat granulosa cells (Mansfield et al. 2003, Tosca et al. 2006b, 2007, Rice et al. 2009). However, the effects of metformin on chicken ovarian follicular cells have never been investigated. A better understanding of the cellular effects of metformin at the ovarian level could elucidate pathways that could be targeted for increasing egg production in broiler breeder hens.

In the present study, we hypothesized that treatment of broiler breeder hen granulosa cells with metformin affects FSH-induced signaling networks involving follicular cell proliferation, differentiation, and steroidogenesis. The main objectives of the present study are (i) to determine the molecular mechanisms by which metformin affects FSH-induced signal transduction events in granulosa cells isolated from the most recently recruited preovulatory follicle and prehierarchical follicles, (ii) to determine if metformin affects the expression of genes related to steroidogenesis in granulosa cells, and (iii) to determine the extent to which metformin affects progesterone secretion from granulosa cells.

\section{Materials and methods}

\section{Animals and reagents}

All animal procedures described herein were approved by Pennsylvania State University's Institutional Animal Care and Use Committee. A commercial strain of broiler breeder hens (Cobb 500) was maintained from day-old chicks at the Poultry Education and Research Center at The Pennsylvania State University (University Park, PA). The chickens were reared according to the Cobb 500 Breeder Management Guide and photostimulated beginning at 21 weeks of age. The light was increased accordingly as they came into lay and were provided with a $16 \mathrm{~h}$ light: $8 \mathrm{~h}$ darkness cycle photoperiod for the duration of the study. The broiler breeder hens were feedrestricted according to the Cobb Breeder Management Guide and provided with water ad libitum. To ensure ovulation had yet to occur at the time of killing, hens were palpated via the cloaca for the presence of a hard-shelled egg in the shell gland.

\section{Tissue collection and granulosa cell cultures}

Broiler breeder hens (35-45 weeks old) were killed by cervical dislocation to collect the ovary. Ovarian follicles were grouped by stage of maturation into prehierarchical follicles $(3-5$ and 6-8 $\mathrm{mm}$ ) and preovulatory follicles (9-12 $\mathrm{mm}$ and F5/6). The granulosa cell layer from each follicle was collected as described previously (Krzysik-Walker et al. 2007, Maddineni et al. 2008) and was pooled from four hens to form one biological replicate $(n=4)$. Following three washes in DMEM with high glucose (Sigma Aldrich), granulosa cells were dispersed by gentle repeated pipetting by glass Pasteur pipet as previously described (Tilly \& Johnson 1987, Krzysik-Walker et al. 2007). Cell viability was determined by trypan blue exclusion test.

\section{Effect of metformin on granulosa cell gene expression and signal transduction}

Approximately 140,000-240,000 granulosa cells were placed into each $12 \times 75 \mathrm{~mm}$ polypropylene tube (VWR, Radnor, PA) containing $1 \mathrm{~mL}$ of DMEM supplemented with $2.5 \%$ fetal bovine serum (FBS), $1 \%$ antibiotic-antimycotic solution (Gibco), 1× non-essential amino acids (Corning), recombinant human $\mathrm{FSH}(\mathrm{rhFSH}$; 0 or $10 \mathrm{ng} / \mathrm{mL}$; National Hormone Program, Torrance, AC), and metformin (0, 1, 10, or $20 \mathrm{mM}$; Sigma Aldrich). Metformin treatment doses were chosen based on some of the previous studies that investigated the effects of metformin in vitro (Mansfield et al. 2003, Tosca et al. 2006, 2007, Kim et al. 2018b, Wu et al. 2019); however, such concentrations are several-fold higher than the peak plasma concentration of therapeutic doses of metformin in human subjects. The granulosa cell treatments were incubated in a shaking water bath at $41^{\circ} \mathrm{C}$ (chicken body temperature) under ambient air conditions. The cultures were incubated for 1 or $3 \mathrm{~h}$ to determine phospho-AMPK (pAMPK), phospho-ERK (pERK), phospho-ACC (pACC), and phosphoAkt (pAkt) abundance, or to quantify the abundance of $F S H R$, STAR, CYP11A, and HSD3B mRNA, respectively. We chose a $1 \mathrm{~h}$ incubation time to determine the effects of metformin on the abundance of phospho-proteins based on pilot studies (Supplementary Fig. 1, see section on supplementary materials given at the end of this article). Although phospho-protein abundance could be altered by metformin treatment in as little as $15 \mathrm{~min}$, several studies have utilized a much wider range of treatment durations ranging from $1 \mathrm{~h}$ to 7 days (Tosca et al. 2006, 2007, 2010, Cen et al. 2018, Kim et al. 2018b, Zhou et al. 2019). At the end of the 1 or $3 \mathrm{~h}$ treatments, granulosa cells were recovered by centrifugation at $400 \mathrm{~g}$, snap-frozen in liquid nitrogen, and stored at $-80^{\circ} \mathrm{C}$. 


\section{Quantitative real-time PCR analyses}

Total RNA from granulosa cells treated with metformin for $3 \mathrm{~h}$ was extracted using the RNeasy kit (Qiagen). The quality and quantity of RNA were evaluated using a spectrophotometer (Nanodrop, Wilmington, DE). Following on-column DNase-I (Qiagen) treatment, first-strand cDNA was synthesized by reverse transcribing $1 \mu \mathrm{g}$ of total RNA using random hexamers (Promega), $1 \mathrm{mM}$ dNTP mixture (Promega), 2U M-MLV reverse transcriptase (New England BioLabs, Beverly, MA) and $1 \mu \mathrm{L}$ RNase inhibitor (Invitrogen) in $20 \mu \mathrm{L}$ of total volume. A realtime quantitative PCR (qPCR) was performed using cDNA prepared above (four broiler breeder hens/replicate; $n=3$ ) for determination of FSHR, STAR, CYP11A1, HSD3B1 and RPL19 mRNA abundance as described previously (Maddineni et al. 2005, Ramachandran et al. 2007). Each reaction was done in duplicates using 100 ng cDNA, 1X PerfeCTa SYBR Green FastMix, Low ROX (Quantabio, Beverly, MA), and 300 nM forward and reverse primers (Table 1). Average critical loglinear threshold $\left(\mathrm{C}_{\mathrm{T}}\right)$ values for FSHR, STAR, CYP11A1, and HSD3B 1 were expressed as a proportion of RPL19 mRNA $C_{\mathrm{T}}$ values following $2^{-\Delta \Delta C t}$ method (Livak \& Schmittgen 2001) and analyzed. Each qPCR experiment was repeated at least 3 times to serve as internal replications.

\section{Western blot analyses}

Granulosa cells (pooled from four broiler breeder hens/replicate; $n=3$ ) treated with metformin for $1 \mathrm{~h}$ as described above were homogenized in $1 \times$ RIPA lysis buffer $(\mathrm{pH} 7.4 \pm 0.1$ ) (Santa Cruz Biotechnology) supplemented with protease inhibitor cocktail, PMSF, sodium orthovanadate and phosphatase inhibitor cocktails A and B (Santa Cruz Biotechnology). After brief centrifugation, the supernatant was saved and protein concentration was determined by colorimetric detection with a bicinchoninic acid (BCA) assay (Thermo Fisher Scientific) according to the manufacturer's protocol. Western blotting analyses were conducted under reducing conditions, as described previously (Hendricks III et al. 2009) to quantify pAMPK, pERK, pACC, and pAkt abundance. The type of polyacrylamide gel, the amount of cellular proteins used in each blot, and the primary antibodies used are provided in Table 2. Following electrophoresis, proteins were transferred to a PVDF or nitrocellulose membrane and blocked for $1 \mathrm{~h}$ at room temperature with 5\% BSA in TBS supplemented with $0.1 \%$ Tween 20 (pH 7.4; TBST). The blots were incubated with the primary antibodies at $4^{\circ} \mathrm{C}$ overnight. Following a brief wash, membranes were incubated for $1 \mathrm{~h}$ at room temperature with goat anti-rabbit (Thermo Fisher Scientific, Cat\# 31460; 1:5000) or goat anti-mouse (Thermo Fisher Scientific, Cat\# 31430; 1:5000) poly-horseradish peroxidase (HRP) conjugated secondary antibody diluted in blocking solution, respectively. Following washes in TBST, blots were incubated with enhanced chemiluminescent (ECL) Western blotting substrate (Thermo Fisher Scientific) according to the manufacturer's protocol and imaged using ChemiDoc XRS+ Imaging System (Bio-Rad). Bands were scanned into digital images and analyzed by densitometry using Image Lab Software v. 6.0 (Bio-Rad). Following quantification of pAMPK, pERK, pACC, and pAkt signal intensity, the blots were stripped to quantify the abundance of AMPK, ERK, ACC, or Akt (Table 2). For both the phosphorylated and non-phosphorylated target proteins, target band density was normalized to the appropriate loading control prior to analysis, either $\beta$-actin or $\alpha$-tubulin, respectively. $\beta$-Actin and $\alpha$-tubulin, the two cytoskeletal proteins, were selected for normalization as they are least likely to be affected by metformin treatment. The choice of $\beta$-actin or $\alpha$-tubulin for normalization while quantifying a particular target protein was based on the mass so it would not interfere with the bands of the protein of interest. The abundance of pAMPK, pERK, pACC, and pAkt were expressed as a proportion of AMPK, ERK, ACC, or Akt abundance and compared among treatments. Each Western blotting experiment was repeated at least three times to serve as internal replication.

\section{Effect of metformin on granulosa progesterone secretion}

Granulosa cells from prehierarchical follicles $(6-8 \mathrm{~mm})$ to preovulatory follicles ( $\mathrm{F} 5 / 6$ and 9-12 $\mathrm{mm}$ ) were dispersed by gentle repeated pipetting by glass Pasteur pipet into a single

Table 1 The nucleotide sequences of the primers directed towards Gallus gallus mRNA targets used to amplify FSHR, STAR, CYP11A1, HSD3B1 and RPL19. The length of amplicons and GenBank accession number are also provided.

\begin{tabular}{|c|c|c|c|}
\hline Name & Sequence, $5^{\prime}-3^{\prime}$ & GenBank accession no., position & Product length, bp \\
\hline FSHR & & NM_205079 & 127 \\
\hline cFSHRFwd1 & TTGTGATCATCTGCATCTGCTA & & \\
\hline cFSHRRev1 & CAGAGGAAGTCTGTGAAGATCAAT & & \\
\hline STAR & & NM_204686 & 149 \\
\hline cSTARFwd2 & CTGAGCAGCAGGGATTTATCA & & \\
\hline cSTARRev2 & GACCTGGTTGATGATGGTCTTT & & \\
\hline CYP11A1 & & NM_001001756 & 163 \\
\hline cP450Fwd2 & AGCACTTCAAGGGACTGAGCTT & & \\
\hline cP450Rev2 & ACAAGAATGAGGTCGAACTTGGT & & \\
\hline HSD3B1 & & NM_205118 & 142 \\
\hline cHSDFwd1 & AAGTCAACGTGACAGGTACTCAGA & & \\
\hline cHSDRev1 & GGTGTATCTTCATCACCATTGAAA & & \\
\hline RPL19 & & NM_001030929 & 130 \\
\hline RPL19Fwd & CCCAACGAGACCAACGAG & & \\
\hline RPL19Rev & CCAAGGTGTTCTTCCTGCAT & & \\
\hline
\end{tabular}


Table 2 Reagents used for Western blot analyses. All antibodies were purchased from Cell Signaling Technology except anti- $\beta$-actin and anti- $\alpha$-tubulin antibodies that were purchased from Millipore Sigma.

\begin{tabular}{|c|c|c|c|c|c|}
\hline \multirow[b]{2}{*}{ Target } & \multirow{2}{*}{$\begin{array}{c}\text { Protein quantity } \\
\text { used }(\mu \mathrm{g})\end{array}$} & \multirow[b]{2}{*}{ Electrophoresis gel type } & \multicolumn{3}{|l|}{ Primary antibody } \\
\hline & & & Name & Cat\# & Concentration used \\
\hline pAMPK & $15-40$ & $10 \%$ Bis-Tris NuPAGE Novex gels & Rabbit anti-phospho-AMPK $\alpha$ (Thr172) & 2531 & $1: 750^{\ddagger}$ or $1: 1000^{\ddagger \text { for }}$ \\
\hline AMPK & $15-40$ & $10 \%$ Bis-Tris NuPAGE Novex gels & Rabbit anti-AMPK $\alpha$ & 2532 & $1: 750^{\ddagger}$ or $1: 1000^{\text {for }}$ \\
\hline pERK & 10 & $10 \%$ Bis-Tris NuPAGE Novex gels & $\begin{array}{l}\text { Rabbit anti-phospho-p44/42 } \\
\text { MAPK (ERK1/2) (Thr202/Tyr204) }\end{array}$ & 9101 & $1: 1000$ \\
\hline ERK & 10 & $10 \%$ Bis-Tris NuPAGE Novex gels & Rabbit anti-p44/42 MAPK (ERK1/2) & 9102 & $1: 1000$ \\
\hline pACC & $15-40$ & $4-12 \%$ Bis-Tris NuPAGE Novex gels & Rabbit anti-phospho-ACC (Ser79) & 3661 & $1: 750^{\ddagger}$ or $1: 1000^{\text {for }}$ \\
\hline ACC & $15-40$ & $4-12 \%$ Bis-Tris NuPAGE Novex gels & Rabbit anti-ACC & 3662 & $1: 750^{\ddagger}$ or $1: 1000^{\text {for }}$ \\
\hline pAkt & 15 & $10 \%$ Bis-Tris NuPAGE Novex gels & Rabbit anti-phospho-Akt (Ser473) & 9271 & $1: 1000$ \\
\hline Akt & 15 & $10 \%$ Bis-Tris NuPAGE Novex gels & Rabbit anti-Akt & 9272 & $1: 1000$ \\
\hline$\beta$-Actin & - & Membranes re-probed & Mouse anti- $\alpha$-tubulin & T6199 & $0.7 \mu \mathrm{g} / \mathrm{mL}$ \\
\hline$\alpha$-Tubulin & - & Membranes re-probed & Mouse anti- $\beta$-Actin & A5441 & $0.5 \mu \mathrm{g} / \mathrm{mL}$ \\
\hline
\end{tabular}

${ }^{\ddagger}$ 9-12 mm follicle granulosa cells; ${ }^{* \ddagger} 3-5 \mathrm{~mm}$ and $6-8 \mathrm{~mm}$ follicle granulosa cells.

cell suspension using $0.3 \%$ type II collagenase (Worthington Biochemical Corporation, Lakeford, NJ) supplemented with 2\% DNase (Promega). Approximately 0.7-1 million cells/well were seeded in gelatinized 12-well polystyrene culture wells (Corning) containing $1 \mathrm{~mL}$ of M199 with Earle's salts (Sigma Aldrich) supplemented with $0.2 \% \alpha$-D-glucose (Sigma), $1 \times$ insulin-transferrin-selenium solution (Corning), 1\% antibioticantimycotic solution (Gibco) and $1 \times$ non-essential amino acids (Corning) at $37^{\circ} \mathrm{C}$ in an atmosphere of $95 \%$ air and $5 \%$ $\mathrm{CO}_{2}$. These cells were allowed to attach and grow for $24 \mathrm{~h}$ and then cultured for an additional 24, 48, or $72 \mathrm{~h}$. In the absence or presence of $\mathrm{rhFSH}(100 \mathrm{ng} / \mathrm{mL})$ and metformin $(0$, $1,10$, or $20 \mathrm{mM})$. The granulosa cells were cultured at $37^{\circ} \mathrm{C}$ to sustain the bioactivity of the human origin-rhFSH utilized in the assay. In previous studies conducted in our laboratory, there was no difference in responses from chicken granulosa cells or ovarian surface epithelial cells when cultured at $37^{\circ} \mathrm{C}$ or $41^{\circ} \mathrm{C}$. Cell culture media was subsequently collected and stored at $-20^{\circ} \mathrm{C}$ for future progesterone quantification, and attached granulosa cells were collected in RIPA lysis buffer for protein extraction and quantification as described above.

\section{Progesterone enzyme-linked immunosorbent assay}

Granulosa cells ( $n=4$ replicates of four broiler breeder hens each) were cultured as described above, and cell culture media collected. Progesterone concentrations in the cell culture media in response to metformin treatment were quantified by a competitive ELISA as previously described for cell culture medium samples (Petroff et al. 1997, Hughes et al. 2019). Microplates (Corning Costar) were coated with $100 \mu \mathrm{L}$ of goat anti-mouse IgG secondary antibody $(2 \mu \mathrm{g} / \mathrm{mL}$; EMD Millipore) and incubated overnight at $4{ }^{\circ} \mathrm{C}$. Unbound antibody was removed from the plate by washing in wash buffer (5× MOPS stock and 10\% Tween 20; pH 7.2; WB). In total, $100 \mu \mathrm{L}$ of monoclonal mouse anti-progesterone primary antibody (57.8 ng/mL; East Coast Bio, North Berwick, ME) was added to each well except the wells designated to test nonspecific binding and the plate was sealed and incubated on a shaker for $1.5 \mathrm{~h}$. The plate was washed with WB to remove excess primary antibody. In total, $100 \mu \mathrm{L}$ of cell culture media collected from granulosa cell cultures treated with metformin, progesterone standards to generate a standard curve, or the assay buffer to determine non-specific binding was then added in duplicate wells. Progesterone (Cayman Chemical, Ann Arbor, MI) concentrations for the standard curve ranged from 0.078 to $10 \mathrm{ng} / \mathrm{mL}$, with a two-fold difference between each dilution. The concentration for the lower end of the range was chosen to allow quantification of the least amount of progesterone in media typically expected out of prehierarchical follicular granulosa cells. Cell culture media samples were diluted, if necessary, to fit within the progesterone detection limits of the assay. Cell culture media samples and antibodies were diluted in assay buffer $(0.04 \mathrm{M}$ 3-(N-morpholino) propanesulfonic acid, $0.12 \mathrm{M} \mathrm{NaCl}, 0.01 \mathrm{M}$ EDTA, $0.05 \%$ Tween 20, $0.005 \%$ chlorhexidine digluconate, and $0.1 \%$ gelatin; $\mathrm{pH} 7.2$ ). The plates were incubated on a plate shaker for $1.5 \mathrm{~h}$ followed by washes in WB and then $125 \mu \mathrm{L}$ of substrate solution $(0.05 \mathrm{M}$ sodium acetate, $0.5 \mathrm{M}$ hydrogen peroxide, and 3,3',5,5'-tetramethyl benzidine (20 $\mathrm{mg} / \mathrm{mL}$ in dimethyl sulfoxide; TMB) was added to each well. Plates were sealed and incubated at $37^{\circ} \mathrm{C}$ for $15 \mathrm{~min}$, followed by the addition of $50 \mu \mathrm{L}$ of stop solution $\left(0.5 \mathrm{M} \mathrm{H}_{2} \mathrm{SO}_{4}\right)$. Plates were read in a Victor $^{3} 1420$ Multilabel Counter (PerkinElmer, Waltham, MA, USA), and optical density was assessed at 450 $\mathrm{nm}$. All samples were run in duplicates, and each assay was repeated at least 4 times to serve as an internal replication. The intra-assay coefficients of variation for the samples were less than $15 \%$.

\section{Statistical analyses}

All data were subjected to ANOVA using the general linear model (GLM) procedure of the Statistical Analysis System (SAS Institute Inc.; Cary, NC) or GraphPad Prism version 8.0.0. Differences among individual means were determined by using a Tukey's HSD test. A probability level of $\mathrm{P} \leq 0.05$ is considered statistically significant. Data on the effect of metformin on granulosa cell STAR, FSHR, CYP11A1, and HSD3B 1 mRNA abundance were expressed as fold differences normalized to ribosomal protein gene, RPL19. Data on the effect of metformin on granulosa cell pAMPK, pERK, pACC, and pAkt abundance is expressed as a proportion of AMPK, ERK, ACC or Akt abundance, respectively, and compared among 
A 3-5 $\mathrm{mm}$
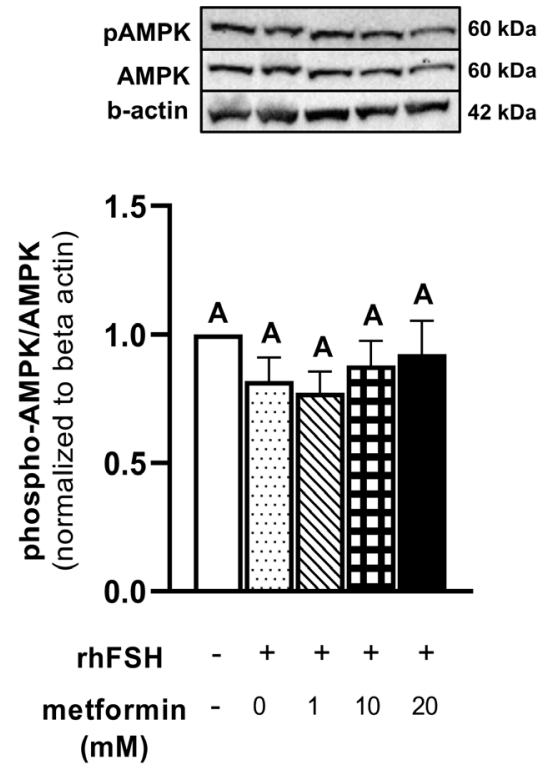

B
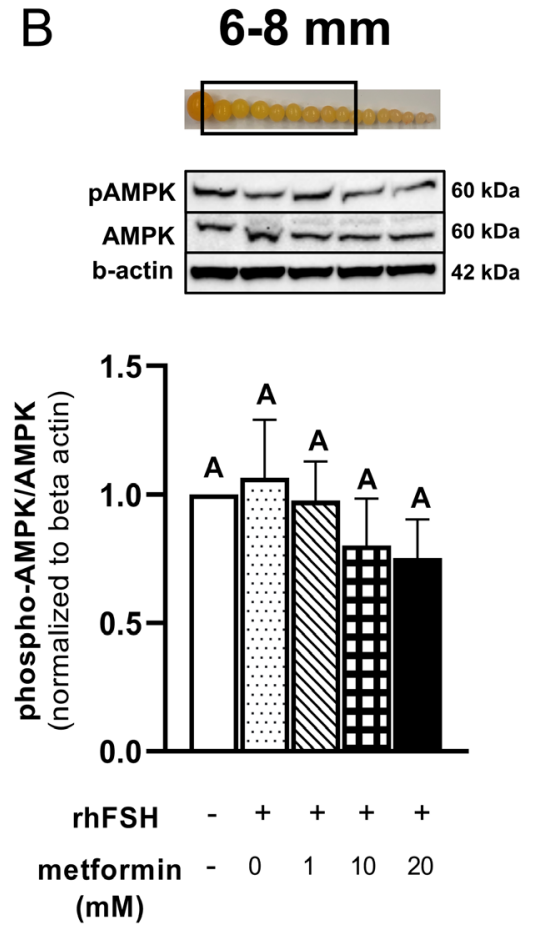

C 9-12 mm
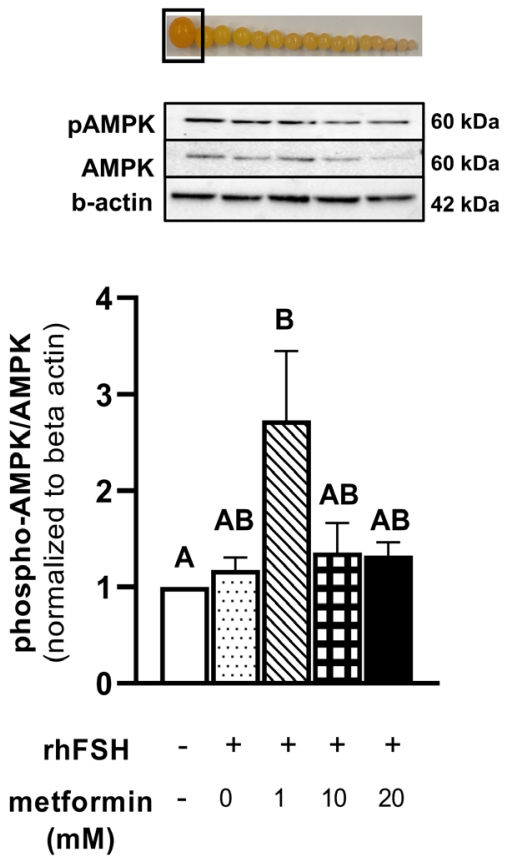

Figure $1(A-C)$ Western blot analysis on the effect of metformin on pAMPK and AMPK abundance in granulosa cells. Granulosa cells from prehierarchical follicles (3-5 and 6-8 $\mathrm{mm}$ ) to preovulatory follicles (9-12 $\mathrm{mm}$ ) were dispersed into single-cell suspension and treated with 0, 1, 10 , or $20 \mathrm{mM}$ metformin for $60 \mathrm{~min}$ in the presence or absence of rhFSH $(10 \mathrm{ng} / \mathrm{mL})$ at $41^{\circ} \mathrm{C}$. Cell lysates were prepared following treatment, and a Western blot analysis was performed under reducing conditions to quantify the abundance of pAMPK, AMPK, and $\beta$-actin. Control received no rhFSH and no metformin. $\beta$-Actin is used as a protein loading control. ${ }^{\mathrm{A}, \mathrm{B}} P<0.05$ by ANOVA; $n=3$ replicates of four broiler breeder hens each. Inset: Photograph of prehierarchical follicles and the most-recently recruited preovulatory follicle to denote the source of granulosa cell (open box).

the treatments. Progesterone concentrations in the cell culture media were normalized to total cellular protein concentrations in each well and analyzed using ANOVA as described above, which also included ELISA plate as a covariate in the model. All data are represented as mean \pm S.E.M.

\section{Results}

\section{Effect of metformin on granulosa cell $p A M P K$ and pACC abundance}

Metformin treatment had no effect on the abundance of pAMPK in granulosa cells isolated from $3-5$ to $6-8$ $\mathrm{mm}$ prehierarchical follicles (Fig. 1A and B). In contrast, metformin treatment at $1 \mathrm{mM}$ level significantly increased the abundance of pAMPK in granulosa cells isolated from the most recently recruited preovulatory $(9-12 \mathrm{~mm}$ ) follicle while phosphorylation of AMPK in response to metformin treatments at 10 and $20 \mathrm{mM}$ did not differ from the controls (Fig. 1C). The abundance of pACC in granulosa cells isolated from 3-5 to 6-8 prehierarchical follicles and the most recently recruited 9-12 $\mathrm{mm}$ preovulatory follicle did not differ in response to metformin treatment when compared to vehicle treatment (Fig. 2A, B and C). However, the abundance of pACC was significantly greater in response to $1 \mathrm{mM}$ metformin treatment when compared with $20 \mathrm{mM}$ metformin treatment in 9-12 mm follicular granulosa cells.

\section{Effect of metformin on granulosa cell pERK and pAKT abundance}

Metformin treatment of granulosa cells isolated from prehierarchical follicles (3-5 and 6-8 $\mathrm{mm}$ ) to the mostrecently recruited preovulatory follicle $(9-12 \mathrm{~mm})$ significantly decreased the abundance of pERK and pAkt in a dose-dependent manner, with 10 and $20 \mathrm{mM}$ having the most significant effect (Figs 3 and 4).

\section{Effect of metformin on granulosa cell gene expression}

Treatment of granulosa cells isolated from prehierarchical follicles (3-5 and 6-8 $\mathrm{mm}$ ) to the most-recently recruited preovulatory follicle $(9-12 \mathrm{~mm})$ with 1,10 , or $20 \mathrm{mM}$ metformin, significantly decreased the abundance of FSHR mRNA (Fig. 5A, B and C). We observed a lesser abundance of STAR mRNA in granulosa cells isolated from $6-8 \mathrm{~mm}$ to $9-12 \mathrm{~mm}$ follicles when treated with metformin at 10 or $20 \mathrm{mM}$ compared to 0 or 1 $\mathrm{mM}$ metformin treatment (Fig. 6B and C). However, metformin treatment at $0,1,10$, or $20 \mathrm{mM}$ levels resulted in a significantly lesser abundance of STAR mRNA in 3-5 
A
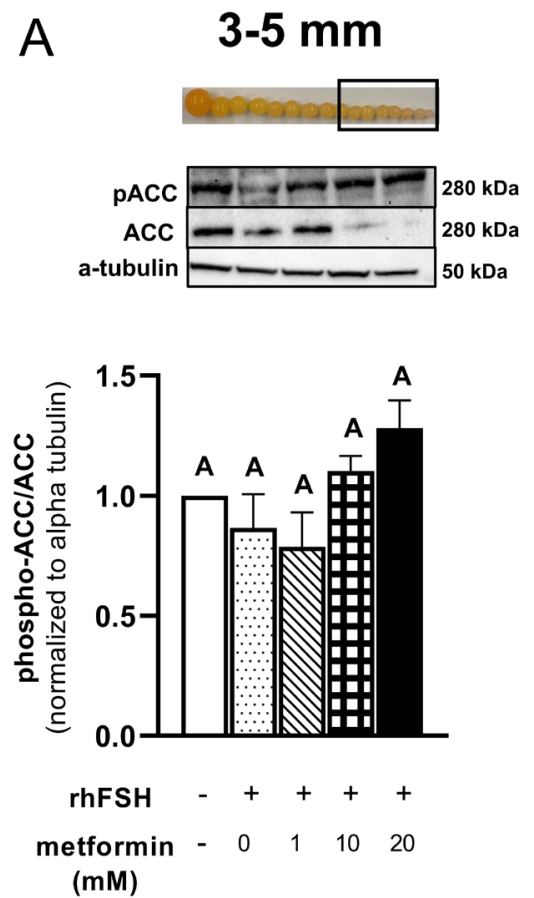

B

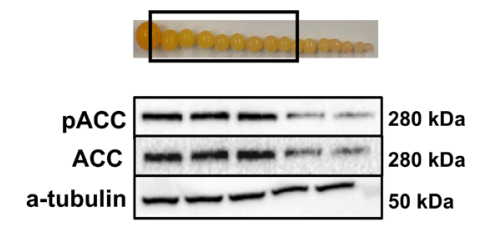

6-8 $\mathrm{mm}$

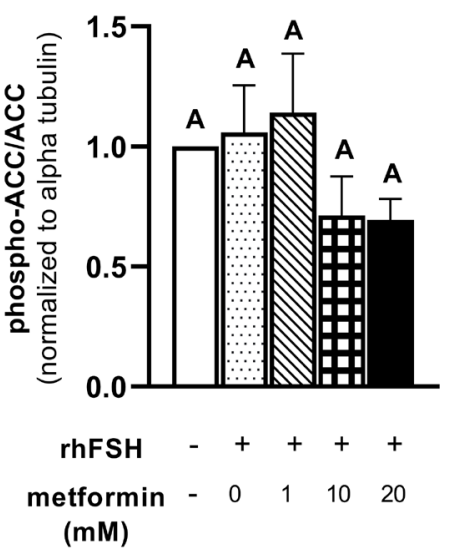

C

9-12 $\mathrm{mm}$

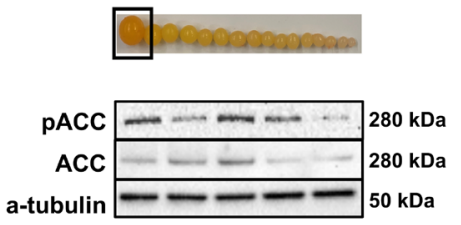

Figure 2 (A-C) Western blot analysis on the effect of metformin on pACC and ACC abundance in granulosa cells. Granulosa cells from prehierarchical follicles (3-5 and 6-8 $\mathrm{mm}$ ) to preovulatory follicles (9-12 $\mathrm{mm}$ ) were dispersed into single-cell suspension and treated with 0, 1, 10, or $20 \mathrm{mM}$ metformin for $60 \mathrm{~min}$ in the presence or absence of rhFSH $(10 \mathrm{ng} / \mathrm{mL})$ at $41^{\circ} \mathrm{C}$. Cell lysates were prepared following treatment, and a Western blot analysis was performed under reducing conditions to quantify the abundance of pACC, ACC, and $\alpha$-tubulin. Control received no rhFSH and no metformin. $\alpha$-tubulin is used as a protein loading control. ${ }^{\mathrm{A}, \mathrm{B}} P<0.05$ by ANOVA; $n=3$ replicates of four broiler breeder hens each. Inset: Photograph of prehierarchical follicles and the most-recently recruited preovulatory follicle to denote the source of granulosa cell (open box).

mm follicular granulosa cells when compared to the cells that received no metformin and were only stimulated with rhFSH (Fig. 6A). In the same cell population, the abundance of CYP11A1 mRNA was lesser in response to $20 \mathrm{mM}$ metformin treatment compared to $0 \mathrm{mM}$ level (Fig. 7A). In 6-8 mm follicular granulosa cells, a dose-dependent decrease in CYP11A1 abundance was observed when treated with metformin at $0,1,10$, or $20 \mathrm{mM}$ (Fig. 7B). In 9-12 mm follicular granulosa cells, metformin treatment at 1,10 , or $20 \mathrm{mM}$ levels resulted in a lesser abundance of CYP11A1 mRNA compared to the cells that received no metformin treatment and were only stimulated with rhFSH (Fig. 7C). While metformin treatment had no effect on the abundance of HSD $3 B 1$ mRNA in 3-5 mm follicular granulosa cells, a dose of 10 , or $20 \mathrm{mM}$ metformin treatment resulted in a lesser abundance of HSD3B1 mRNA in 6-8 mm granulosa cells compared to 0 and $1 \mathrm{mM}$ metformin treatment (Fig. $8 \mathrm{~A}$ and $\mathrm{B}$ ). A dose-dependent decrease in the abundance of HSD3B1 mRNA in 9-12 mm follicular granulosa cells was observed in response to $0,1,10$, or $20 \mathrm{mM}$ metformin treatment (Fig. 8C).

\section{Effect of metformin on progesterone secretion}

Treatment of granulosa cells isolated from 6 to $8 \mathrm{~mm}$ prehierarchical follicle with 10 or $20 \mathrm{mM}$ metformin resulted in a decrease in progesterone concentrations back to the levels observed with the control (Fig. 9A, B and C) at $72 \mathrm{~h}$ of treatment, but not at 24 and $48 \mathrm{~h}$. A dose-dependent decrease in progesterone concentration was observed when granulosa cells isolated from the most recently recruited preovulatory follicle $(9-12 \mathrm{~mm})$ were treated with metformin for 24,48 , or 72 h with 20 $\mathrm{mM}$ of metformin having the most-significant effect (Fig. 9D, E and F). Similar to 9-12 mm follicular granulosa cells, treatment of the smallest preovulatory follicle (F5) granulosa cells with metformin decreased progesterone concentrations in a dose-dependent manner at 24, 48 and $72 \mathrm{~h}$ of culture with 10 and $20 \mathrm{mM}$ of metformin having the most-significant effect (Fig. 9G, $\mathrm{H}$ and I).

\section{Discussion}

We report for the first time that metformin decreases progesterone secretion from granulosa cells isolated from prehierarchical and preovulatory follicles of the chicken ovary. Such attenuation of steroidogenesis in response to metformin was associated with a diminished expression of genes related to steroidogenesis and decreased phosphorylation of ERK1/2 and Akt. Our results suggest that metformin treatment did not affect the phosphorylation of AMPK in granulosa cells isolated from prehierarchical follicles. However, metformin 
A

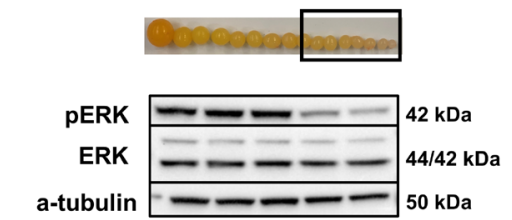

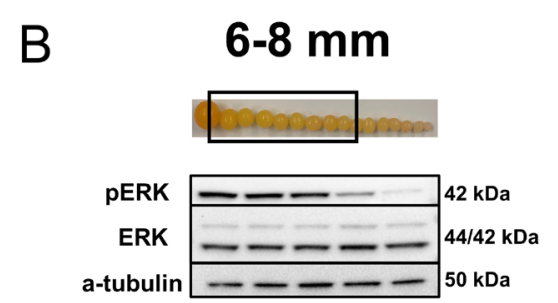

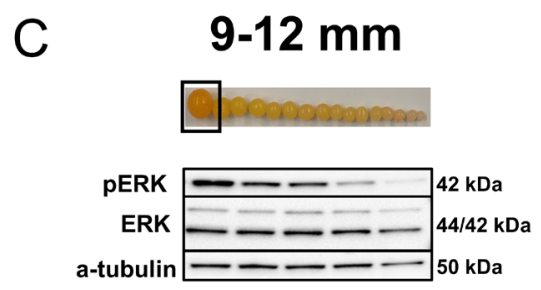

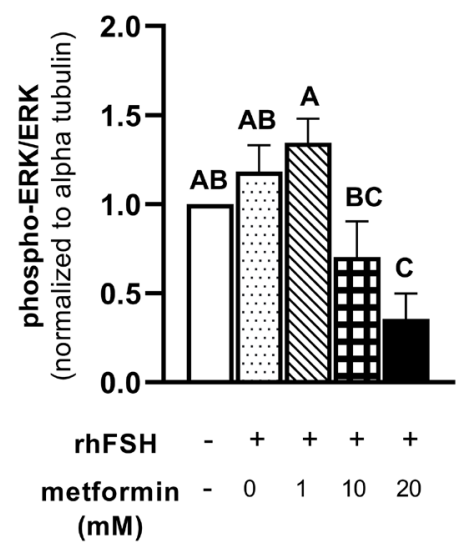
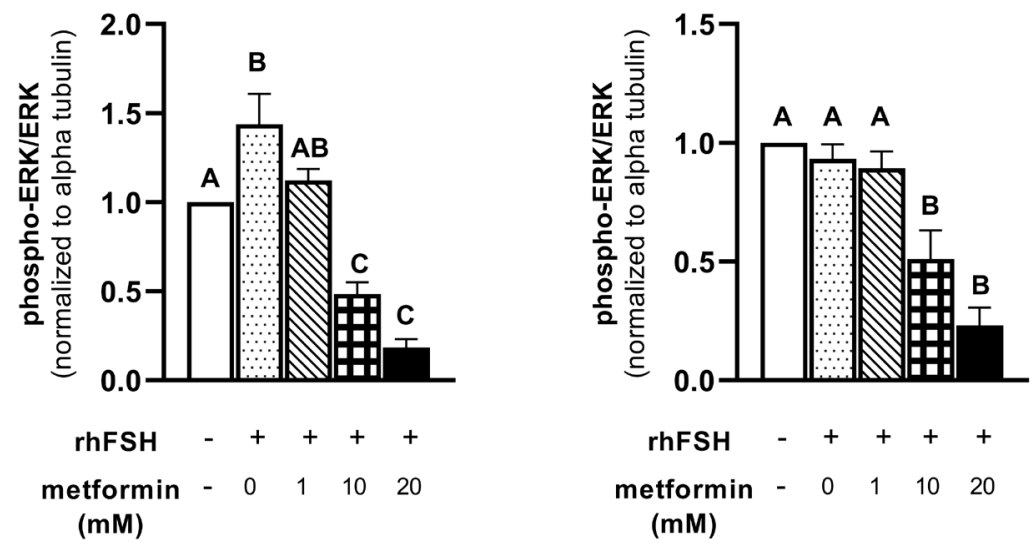

Figure 3 (A-C) Western blot analysis on the effect of metformin on pERK1/2 and ERK abundance in granulosa cells. Granulosa cells from prehierarchical follicles (3-5 and 6-8 $\mathrm{mm}$ ) to preovulatory follicles (9-12 $\mathrm{mm}$ ) were dispersed into single-cell suspension and treated with 0 , 1, 10 , or $20 \mathrm{mM}$ metformin for $60 \mathrm{~min}$ in the presence or absence of $\mathrm{rhFSH}(10 \mathrm{ng} / \mathrm{mL})$ at $41^{\circ} \mathrm{C}$. Cell lysates were prepared following treatment, and a Western blot analysis was performed under reducing conditions to quantify the abundance of pERK1/2, ERK $1 / 2$, and $\beta$-actin. Control received no rhFSH and no metformin treatments. $\beta$-Actin is used as a protein loading control. $\mathrm{A}, \mathrm{B}, \mathrm{C} P<0.001$ by $\mathrm{ANOVA} ; n=4$ replicates of four broiler breeder hens each. Inset: Photograph of prehierarchical follicles and the most-recently recruited preovulatory follicle to denote the source of granulosa cell (open box).

appears to have a biphasic effect on activation of AMPK in granulosa cells of the most-recently recruited 9-12 $\mathrm{mm}$ preovulatory follicle, as $1 \mathrm{mM}$ metformin treatment increased pAMPK abundance, an effect that was reversed by higher levels of metformin. The expression of AMPK and its ability to respond to AICAR by increased phosphorylation in granulosa and theca cells of preovulatory follicles (F1-F4) of leghorn chickens has been previously documented (Tosca et al. 2006). While no data exists on the effect of metformin on chicken granulosa cells, several studies indicate that metformin treatment increases phosphorylation of AMPK of rat (Tosca et al. 2006), bovine (Tosca et al. 2007), and human (Kai et al. 2015) granulosa cells. A lack of effect on AMPK phosphorylation in response to metformin treatment in the present study potentially reflects species variation and suggest that metformin is least likely to act via AMPKdependent pathway in undifferentiated granulosa cells. Metformin has been found to act via AMPK-independent pathways such as inhibition of mitochondrial respiration (Owen et al. 2000), decreased phosphorylation of ERK1/2 (Tosca et al. 2007), downregulation of mTORC (Kalender et al. 2010) and a decrease in the production of cAMP (Miller et al. 2013). In addition, metformin decreases hepatic gluconeogenesis by inhibiting several enzymes involved in gluconeogenesis in an AMPKindependent manner (Foretz et al. 2010). Taken together, metformin treatment at all dosages is likely to be acting primarily through an AMPK-independent pathway in undifferentiated granulosa cells of prehierarchical follicles but may act by either AMPK-independent or AMPK-dependent pathways depending on the dose in actively differentiating granulosa cells.

We investigated the effect of metformin on the abundance of ACC due to the critical role of pACC in decreasing fatty acid synthesis by inhibiting the conversion of acetyl-CoA to malonyl-CoA (Fullerton et al. 2013). Our results suggest that metformin had no effect on phosphorylation of ACC in granulosa cells isolated from prehierarchical follicles or the most recently recruited preovulatory follicle. Given that metformin did not affect AMPK phosphorylation in our study, it is not surprising to expect a lack of effect of metformin on phosphorylation of ACC, which is one of the pAMPK downstream targets. While this data may confirm the dependency of ACC for its activation on activation of AMPK, further studies are essential to clarify the role of metformin on granulosa cell fatty acid metabolism as it is related to energy homeostasis and steroidogenesis.

Our data suggest that metformin decreases the phosphorylation of ERK2, in a dose-dependent manner, in granulosa cells isolated from both prehierarchical follicles and the most recently recruited preovulatory 
A 3-5 $\mathrm{mm}$
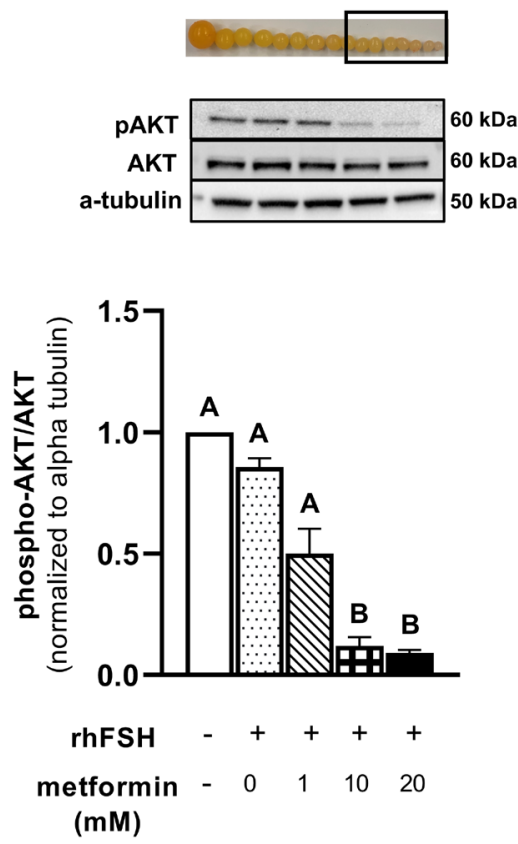

$\mathrm{B}$

6-8 $\mathrm{mm}$
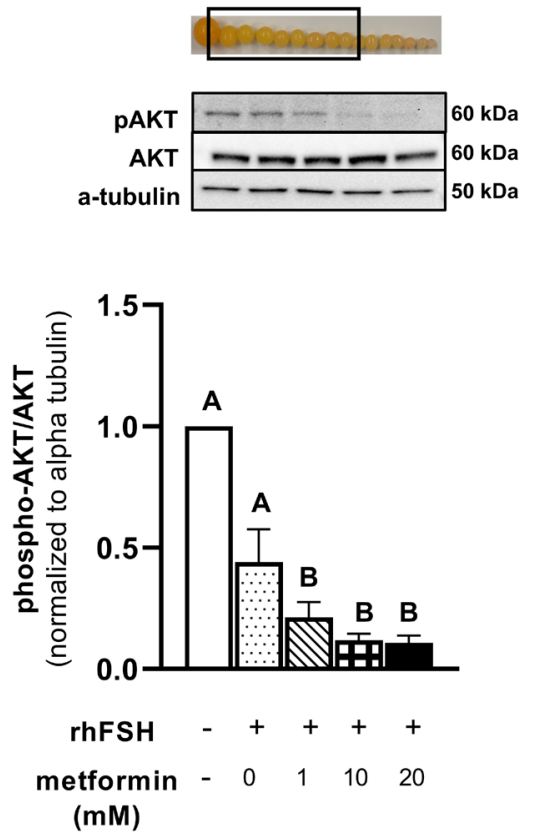
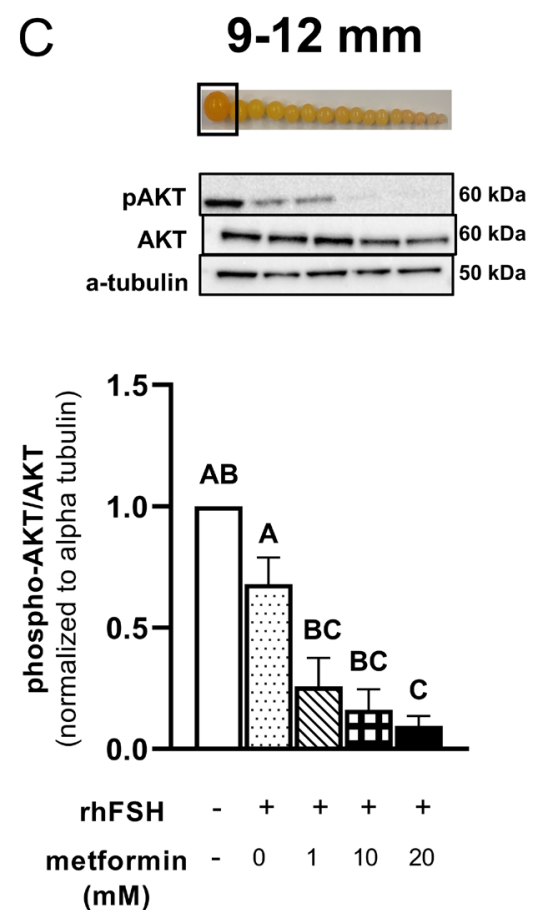

Figure $4(\mathrm{~A}-\mathrm{C})$ Western blot analysis on the effect of metformin on pAKT and AKT abundance in granulosa cells. Granulosa cells from prehierarchical follicles (3-5 and 6-8 $\mathrm{mm}$ ) to preovulatory follicles $(9-12 \mathrm{~mm}$ ) were dispersed into single-cell suspension and treated with 0 , 1, 10 , or $20 \mathrm{mM}$ metformin for $60 \mathrm{~min}$ in the presence or absence of rhFSH $(10 \mathrm{ng} / \mathrm{mL})$ at $41^{\circ} \mathrm{C}$. Cell lysates were prepared following treatment, and a Western blot analysis was performed under reducing conditions to quantify the abundance of pERK1/2, ERK1/2 and $\beta$-actin. Control received no rhFSH and no metformin treatments. $\beta$-Actin is used as a protein loading control. ${ }^{\mathrm{A}, \mathrm{B}, \mathrm{C}} P<0.001$ by ANOVA; $n=4$ replicates of four broiler breeder hens each. Inset: Photograph of prehierarchical follicles and the most-recently recruited preovulatory follicle to denote the source of granulosa cell (open box).
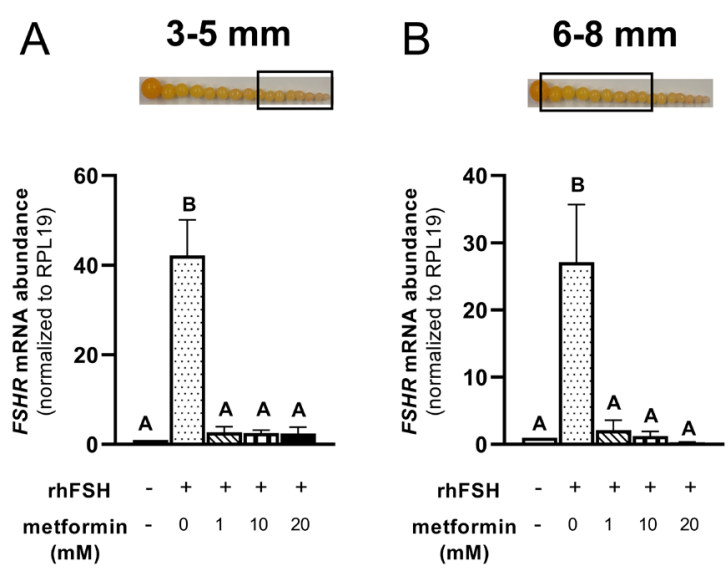
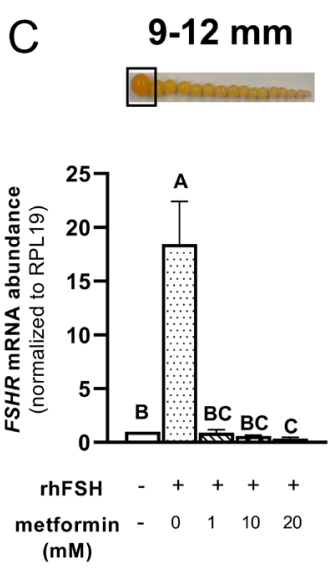

Figure 5 (A-C) Effect of metformin on FSHR $m R N A$ abundance in granulosa cells. Granulosa cells from prehierarchical follicles (3-5 and 6-8 $\mathrm{mm}$ ) to preovulatory follicles (9-12 mm) were dispersed into single-cell suspension and treated with $0,1,10$, or 20 $\mathrm{mM}$ metformin for $180 \mathrm{~min}$ in the presence or absence of rhFSH $(10 \mathrm{ng} / \mathrm{mL})$ at $41{ }^{\circ} \mathrm{C}$. Control received no rhFSH and no metformin treatments. Total RNA extracted from granulosa cell to reverse transcribed. Approximately $100 \mathrm{ng}$ of cDNA was used in quantitative PCR to quantify FSHR $m R N A$ or RPL19 mRNA in separate reactions. Each reaction was run in duplicates, and the critical threshold $\left(C_{T}\right)$ values were averaged, subtracted from that of RPL19 mRNA, and converted from log-linear to linear terms. Data were standardized to RPL19 mRNA and expressed as fold-difference vs control. ${ }^{A, B}, C P$ $<0.001 ; n=4$ replicates of four broiler breeder hens each. Inset: Photograph of prehierarchical follicles and the most-recently recruited preovulatory follicle to denote the source of granulosa cell (open box). 
A
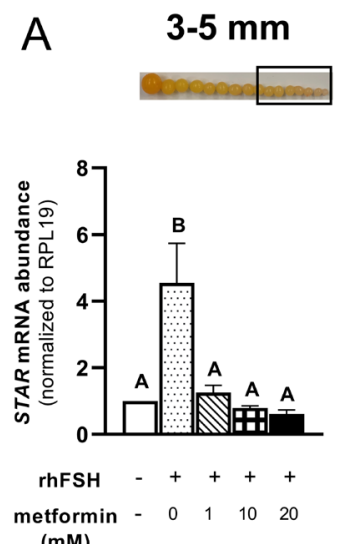

(mM)
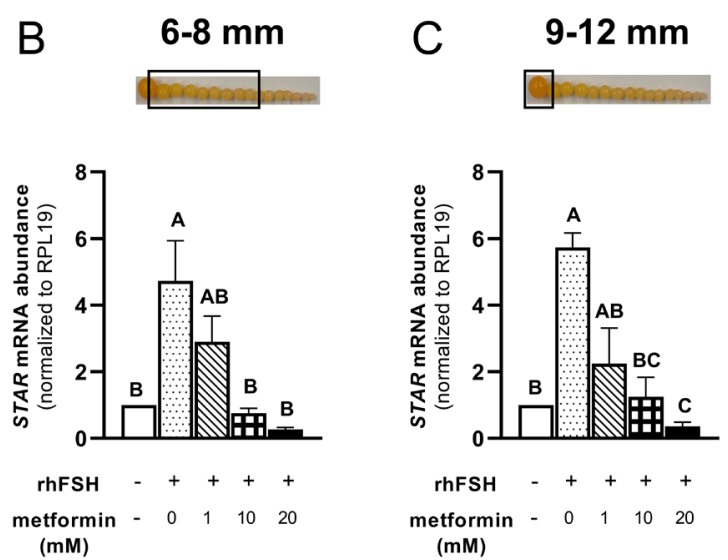

Figure 6 (A-C) Effect of metformin on STAR $m R N A$ abundance in granulosa cells. Granulosa cells from prehierarchical follicles (3-5 and 6-8 $\mathrm{mm}$ ) to preovulatory follicles (9-12 mm) were dispersed into single-cell suspension and treated with $0,1,10$, or 20 $\mathrm{mM}$ metformin for $180 \mathrm{~min}$ in the presence or absence of rhFSH $(10 \mathrm{ng} / \mathrm{mL})$ at $41^{\circ} \mathrm{C}$. Control received no rhFSH and no metformin treatments. Total RNA was extracted and subjected to quantitative real-time PCR as described in the legend to Fig. 5. Data were standardized to RPL19 mRNA and expressed as fold-difference vs control. ${ }^{A}, B, C P<0.001$; $n=4$ replicates of four broiler breeder hens each. Inset: Photograph of prehierarchical follicles and the most-recently recruited preovulatory follicle to denote the source of granulosa cell (open box). follicle. These results are consistent with previous reports of metformin inhibiting the phosphorylation of ERK1/2 in bovine and rat granulosa cells (Tosca et al. 2006, 2007). Activation of mitogen-activated protein kinases (MAPK) results in phosphorylation of several cytoplasmic substrates affecting cellular proliferation and steroidogenesis in human, bovine, and rat granulosa cells (Tajima et al. 2003, 2005, Tosca et al. 2005, 2006, Zhou et al. 2013). Although very few studies have been conducted analyzing the roles of the MAPK signaling pathways in the ovary of the laying hen, it has previously been reported that ERK1/2 acts as a negative regulator of FSH-induced signaling and in part, maintains granulosa cells of prehierarchical follicles in an undifferentiated state (Woods \& Johnson 2005, Johnson 2015, Johnson \& Lee 2016). Based on our findings, it is likely that metformin treatment could contribute to restricting precocious maturation of prehierarchical follicles by maintaining the cells in a quiescent state. The antiERK1/2 antibody and the anti-pERK1/2 antibody used in the present study are expected to detect both ERK1,
ERK2, and pERK1, pERK2, respectively. It is intriguing to note that our data suggest that ERK 1 (44 kDa) may be expressed in addition to ERK 2 (42 kDa) in the chicken granulosa cells. However, we found that anti-pERK1/2 antibody detects only pERK2 band. This is potentially due to poor or no cross-reactivity of the human anti-pERK1/2 antibody to detect chicken pERK1. Previous reports have suggested that the ERK1 gene may have been lost in the chicken due to its absence in sequenced chicken genome (Lefloch et al. 2008) and the absence of ERK1 protein in chicken brain protein extracts (Buscà et al. 2015). Furthermore, the chicken genome assemblies are still incomplete due to technical difficulties imposed by the existence of highly stable secondary gene structures (Beauclair et al. 2019). Further studies are required to determine the existence of the ERK1 gene in chickens.

Similar to the effects of metformin on the phosphorylation of ERK1/2, we found that metformin decreases the phosphorylation of Akt in a dosedependent manner. Our results deviate from previous reports suggesting that metformin does not affect
A

\section{3-5 mm}
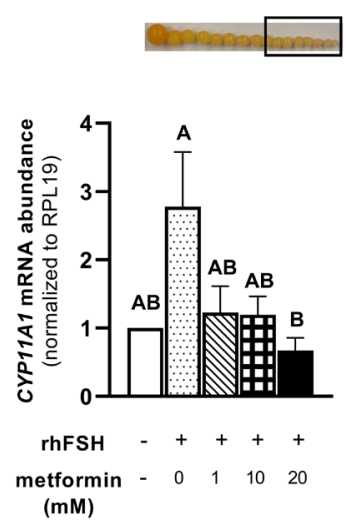

https://rep.bioscientifica.com
Figure 7 (A-C) Effect of metformin on CYP11A1 mRNA abundance in granulosa cells. Granulosa cells from prehierarchical follicles (3-5 and 6-8 $\mathrm{mm}$ ) to preovulatory follicles $(9-12 \mathrm{~mm}$ ) were dispersed into single-cell suspension and treated with 0,1 , 10 , or $20 \mathrm{mM}$ metformin for $180 \mathrm{~min}$ in the presence or absence of $\mathrm{rhFSH}(10 \mathrm{ng} / \mathrm{mL})$ at $41^{\circ} \mathrm{C}$. Control received no rhFSH and no metformin treatments. Total RNA was extracted and subjected to quantitative real-time PCR as described in Fig. 5 legend. Data were standardized to RPL19 mRNA and expressed as fold-difference vs control. $A, B, C, D P$ $<0.001 ; n=4$ replicates of four broiler breeder hens each. Inset: Photograph of prehierarchical follicles and the most-recently recruited preovulatory follicle to denote the source of granulosa cell (open box). 
A 3-5 mm
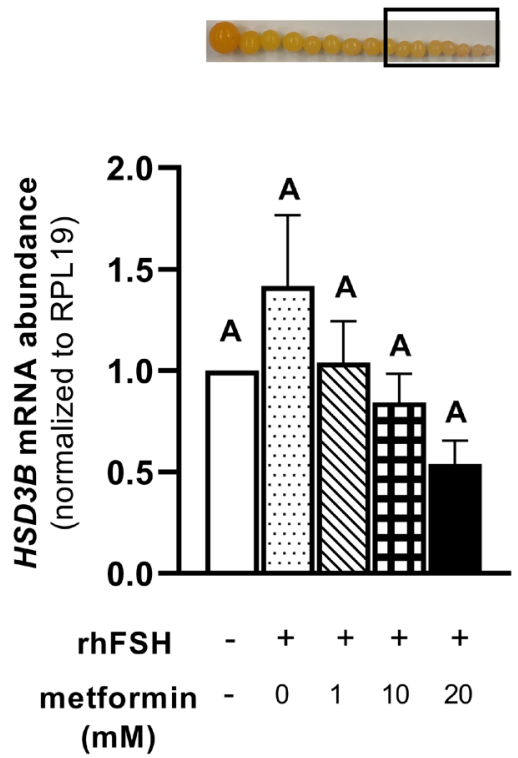

B 6-8 $\mathrm{mm}$
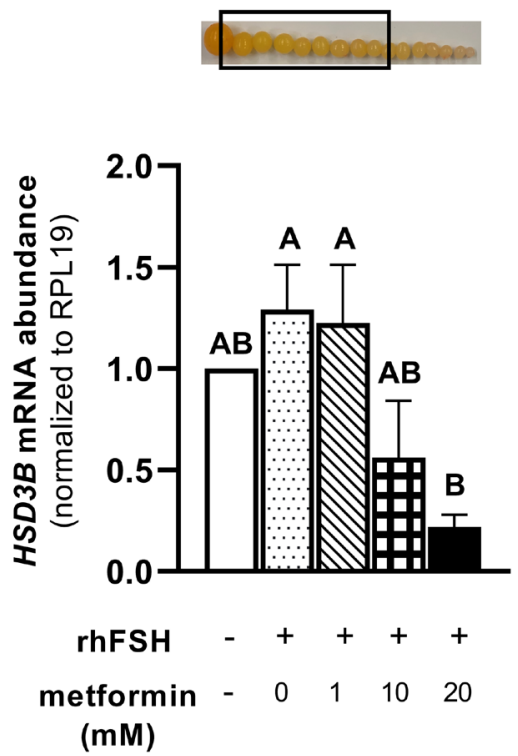

C $\quad 9-12 \mathrm{~mm}$

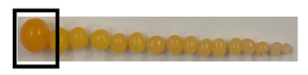

Figure 8 (A-C) Effect of metformin on HSD3B1 mRNA abundance in granulosa cells. Granulosa cells from prehierarchical follicles (3-5 and 6-8 $\mathrm{mm}$ ) to preovulatory follicles $(9-12 \mathrm{~mm}$ ) were dispersed into single-cell suspension and treated with $0,1,10$, or $20 \mathrm{mM}$ metformin for $180 \mathrm{~min}$ in the presence or absence of $\mathrm{rhFSH}(10 \mathrm{ng} / \mathrm{mL})$ at $41^{\circ} \mathrm{C}$. Control received no rhFSH and no metformin treatments. Total RNA was extracted and subjected to quantitative real-time PCR as described in Fig. 5 legend. Data were standardized to RPL19 mRNA and expressed as fold-difference vs control. ${ }^{A}, \mathrm{~B}, \mathrm{C} P<0.001 ; n=4$ replicates of four broiler breeder hens each. Inset: Photograph of prehierarchical follicles and the most-recently recruited preovulatory follicle to denote the source of granulosa cell (open box).

phosphorylation of Akt in bovine granulosa cells (Tosca et al. 2007). Such discordance in data may possibly due to differences in the species studied. There is evidence to support that PI3K/Akt signaling is critical for the maintenance of the preovulatory follicle granulosa layer as inhibitors of PI3K were found to induce apoptosis (Johnson et al. 2001). Similar to chicken granulosa cells, the survival of porcine granulosa cells depend on Akt signaling pathway (Westfall et al. 2000). In addition, activation of the PI3K/Akt signaling pathway is associated with increased steroidogenesis in rat ovarian granulosa cells (Chen et al. 2007), and in bovine theca cells (Fukuda et al. 2009). Based on the foregoing, it is probable that the metformin-induced decrease in the phosphorylation of Akt is potentially related to the decrease in steroidogenesis observed in the present study.

We observed that treatment with metformin decreased the expression of some of the genes related to progesterone biosynthesis, including FSHR, STAR, CYP11A1, and HSD3B. Our data are in agreement with previous studies using human, rat, and bovine granulosa cells (Vrbikova et al. 2001, Mansfield et al. 2003, Tosca et al. 2006, 2007). Consistent with the gene expression data, we found that metformin treatment decreases progesterone production in a dose- and timedependent manner in granulosa cells isolated from both prehierarchical $(6-8 \mathrm{~mm})$ and preovulatory $(9-12 \mathrm{~mm}$ and F5) follicles. Considering the above, it is important to determine the effect of metformin on the abundance of STAR, CYP11A1, and HSD3B at the protein level to confirm the decrease in progesterone secretion as observed in this study. Metformin treatment decreases progesterone and estradiol secretion from bovine granulosa cells in a dose-dependent manner (Tosca et al. 2007). The observed decrease in progesterone secretion in response to metformin treatment is aligned with a decrease in the abundance of pERK and pAkt and a decrease in expression of the genes related to steroidogenesis. Consistent with our in vitro data using granulosa cells, treatment of 6-week-old chickens with metformin for 3 weeks resulted in a 50\% decrease circulating levels of testosterone and reduction in testicular weight despite no change observed in pERK or pAkt (Faure et al. 2016). In the present study, we found that granulosa cells from prehierarchical follicles of broiler breeder hens do secrete progesterone in response to rhFSH stimulation, albeit, requiring sustained stimulation for $72 \mathrm{~h}$. In contrast, granulosa cells obtained from 6 to $8 \mathrm{~mm}$ prehierarchical follicles leghorn chickens were previously reported to be incompetent to produce progesterone and did not respond to ovine $\mathrm{LH}$, ovine FSH, 8-bromo-cyclic AMP or 25-hydroxycholesterol (Tilly et al. 1991, Kim \& Johnson 2018). However, more recent studies have reported low, but detectable, levels of progesterone in the media of cultured undifferentiated leghorn chicken granulosa cells stimulated with rhFSH (Johnson et al. 2001, Ghanem et al. 2019). It is possible 
A

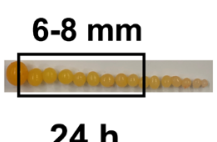

$24 \mathrm{~h}$
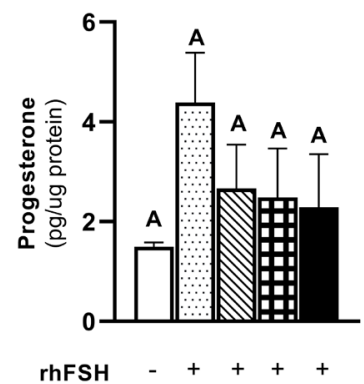

metformin - $\begin{array}{lllll}0 & 1 & 10 & 20\end{array}$ (mM)

D
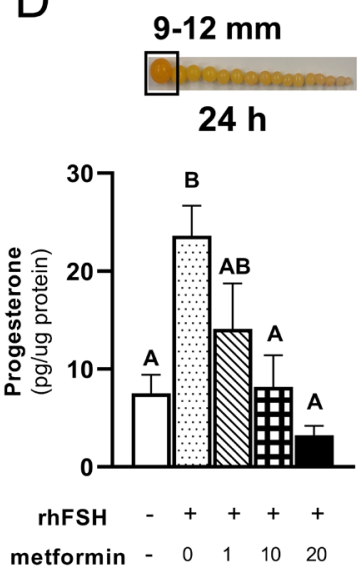

(mM)

G

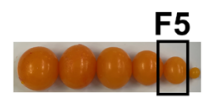

$24 \mathrm{~h}$

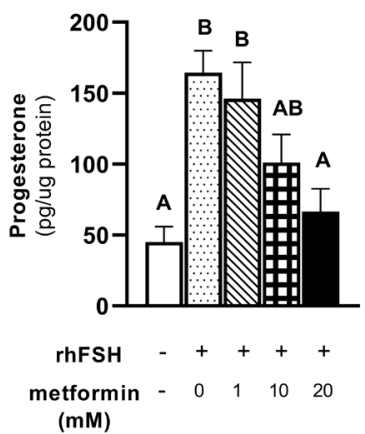

B

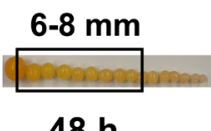

$48 \mathrm{~h}$
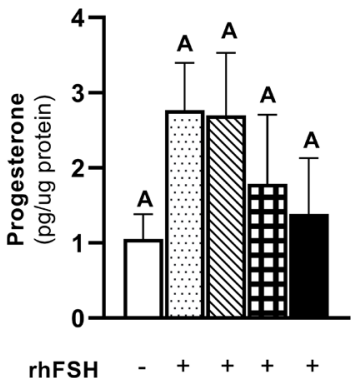

metformin - $\begin{array}{llll}0 & 1 & 10 & 20\end{array}$

(mM)

E
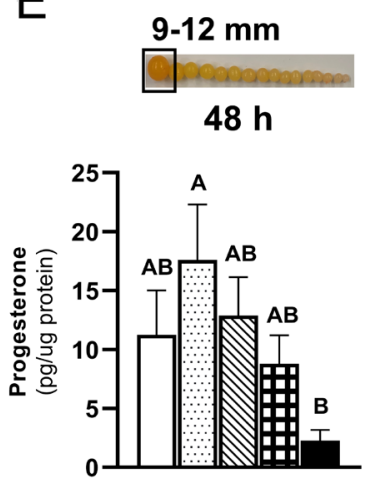

rhFSH - + + +

metformin - $\begin{array}{lllll}0 & 1 & 10 & 20\end{array}$

(mM)

$\mathrm{H}$

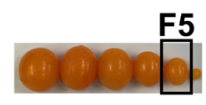

$48 \mathrm{~h}$

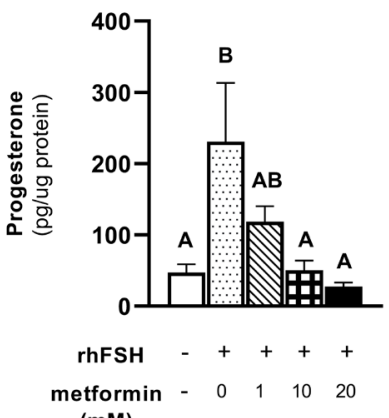

(mM)
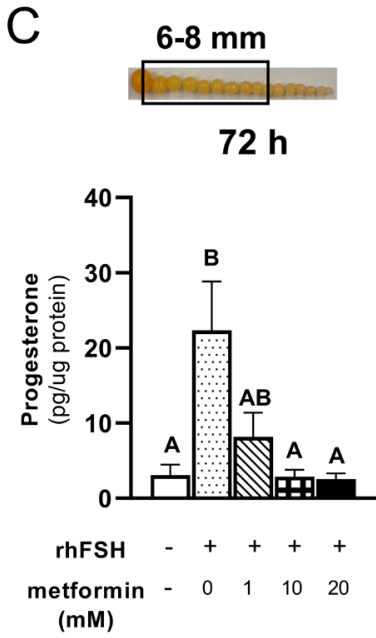

F
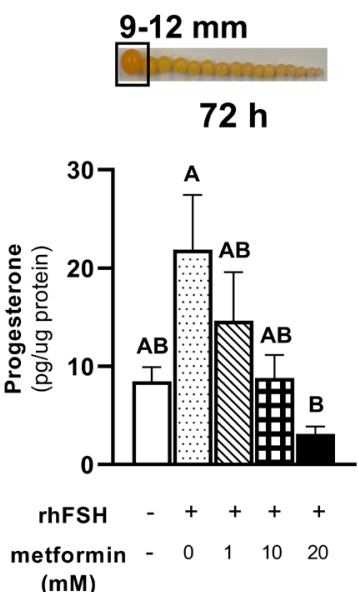

I

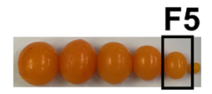

72 h

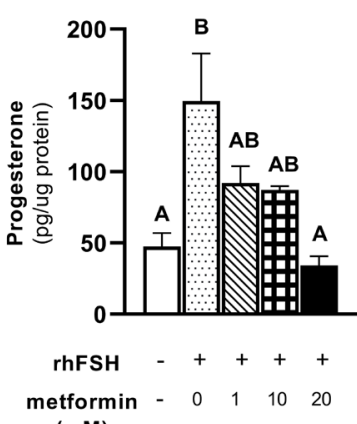

(mM)

Figure $9(\mathrm{~A}-\mathrm{I})$ Effect of metformin on progesterone production in cultured granulosa cells. Granulosa cells from prehierarchical follicles (6-8 $\mathrm{mm}$ ), the most recently recruited preovulatory follicle $(9-12 \mathrm{~mm}$ ) and the smallest preovulatory follicle (F5/6) were cultured and treated with 0 , 1,10 or $20 \mathrm{mM}$ metformin for 24,48 or $72 \mathrm{~h}$ in the presence or absence of rhFSH $(100 \mathrm{ng} / \mathrm{mL})$ at $37^{\circ} \mathrm{C}$. Progesterone concentrations in the cell culture media were quantified by enzyme-linked immunosorbent assay, as described in the 'Materials and methods' section. Progesterone quantity was normalized to the total protein concentrations in the granuloma cell lysate and analyzed. Control received no rhFSH and no metformin treatments. ${ }^{A, B} P<0.05 ; n=4$ replicate incubations of four broiler breeder hens each. Inset: Photograph of prehierarchical follicles and the most-recently recruited preovulatory follicle to denote the source of granulosa cell (open box). 
that isolated granulosa cells may begin the process of differentiation during culture, possibly due to the release from inhibitory influences that exist in vivo. Alternatively, leghorn chickens, as opposed to broiler breeder hens, seldom suffer from excessive recruitment of ovarian follicles and may have a different response to $\mathrm{rhFSH}$. Based on the foregoing, it is likely that sustained stimulation of granulosa cells in prehierarchical follicles by endogenous FSH may underlie excessive recruitment of follicles in broiler breeder hens.

Whereas the exact mechanisms underlying ovarian dysfunction in broiler breeder hens still remain elusive, a pharmacological intervention that corrects the ovarian disorder could increase fertile egg production from broiler breeder hens. Given the beneficial effects of metformin in correcting PCOS in human subjects, a potential role of metformin administration in treating ovarian dysfunction in broiler breeder hens is yet to be determined. While the systemic effects of long term oral administration of metformin to chickens are currently unknown, intravenous bolus injection of metformin daily for 2 weeks to leghorn chickens was associated with a significant decrease in the levels of plasma triglycerides, cholesterol, insulin, as well as a significant decrease in egg production (Chen et al. 2011). Metformin, a drug of choice for treating type 2 diabetes and PCOS is typically administered orally for several months to years. Furthermore, the pharmacokinetics of metformin administered orally vs intravenously differs significantly, and therefore, the biological effects of metformin on reproductive system could be very different following the two routes of administration. As orally administered metformin is bioactive in chickens (Ashwell \& McMurtry 2003, Sato et al. 2011), long term dietary supplementation of metformin to broiler breeder hens is necessary to determine its effects on egg production, fertility and hatchability.

In summary, we provide evidence that metformin decreases progesterone secretion from granulosa cells isolated from broiler breeder hen prehierarchical and preovulatory follicles. Such a decrease in steroidogenesis was found to be associated with the inhibition of ERK2 and Akt signaling pathways and a decrease in the expression of related genes. Our data suggest that metformin has the potential to affect recruitment and maturation of prehierarchical and preovulatory follicles in the broiler breeder hen ovary. Future investigations should be directed toward determining the extent to which metformin could ameliorate ovarian dysfunction and improve fertile egg production in broiler breeder hens.

\section{Supplementary materials}

This is linked to the online version of the paper at https://do i.org/10.1530/REP-20-0066.

\section{Declaration of interest}

The authors declare that there is no conflict of interest that could be perceived as prejudicing the impartiality of the research reported.

\section{Funding}

This project was supported by Agriculture and Food Research Initiative Competitive Grant no. 2017-67015-26506 from the USDA National Institute of Food and Agriculture and in part, by NIH Grant T32GM108563.

\section{Author contribution statement}

Evelyn Weaver designed and conducted the experiments and analyzed data. Both Weaver and Ramesh Ramachandran wrote the manuscript.

\section{References}

Ashwell CM \& McMurtry JP 2003 Hypoglycemia and reduced feed intake in broiler chickens treated with metformin. Poultry Science 82 106-110. (https://doi.org/10.1093/ps/82.1.106)

Beauclair L, Ramé C, Arensburger P, Piégu B, Guillou F, Dupont J \& Bigot Y 2019 Sequence properties of certain GC rich avian genes, their origins and absence from genome assemblies: case studies. BMC Genomics 20 734. (https://doi.org/10.1186/s12864-019-6131-1)

Bertoldo MJ, Faure M, Dupont J \& Ent P 2014 Impact of metformin on reproductive tissues: an overview from gametogenesis to gestation. Annals of Translational Medicine 2 55. (https://doi.org/10.3978/j. issn.2305-5839.2014.06.04)

Buscà R, Christen R, Lovern M, Clifford AM, Yue JX, Goss GG, Pouysségur J \& Lenormand P 2015 ERK1 and ERK2 present functional redundancy in tetrapods despite higher evolution rate of ERK1. BMC Evolutionary Biology 15 179. (https://doi.org/10.1186/s12862-0150450-x)

Cassy S, Metayer S, Crochet S, Rideau N, Collin A \& Tesseraud S 2004 Leptin receptor in the chicken ovary: potential involvement in ovarian dysfunction of ad libitum-fed broiler breeder hens. Reproductive Biology and Endocrinology 2 72. (https://doi.org/10.1186/1477-7827-2-72)

Cen J, Sargsyan E, Forslund A \& Bergsten P 2018 Mechanisms of beneficial effects of metformin on fatty acid-treated human islets. Journal of Molecular Endocrinology 61 91-99. (https://doi.org/10.1530/JME-170304)

Chen SE, McMurtry JP \& Walzem RL 2006 Overfeeding-induced ovarian dysfunction in broiler breeder hens is associated with lipotoxicity. Poultry Science 85 70-81. (https://doi.org/10.1093/ps/85.1.70)

Chen YJ, Hsiao PW, Lee MT, Mason JI, Ke FC \& Hwang JJ 2007 Interplay of $\mathrm{PI} 3 \mathrm{~K}$ and cAMP/PKA signaling, and rapamycin-hypersensitivity in TGF 1 enhancement of FSH-stimulated steroidogenesis in rat ovarian granulosa cells. Journal of Endocrinology 192 405-419. (https://doi.org/10.1677/ JOE-06-0076)

Chen WL, Wei HW, Chiu WZ, Kang CH, Lin TH, Hung CC, Chen MC, Shieh MS, Lee CC \& Lee HM 2011 Metformin regulates hepatic lipid metabolism through activating AMP-activated protein kinase and inducing ATGL in laying hens. European Journal of Pharmacology 671 107-112. (https://doi.org/10.1016/j.ejphar.2011.09.029)

Ehrmann DA, Cavaghan MK, Imperial J, Sturis J, Rosenfield RL \& Polonsky KS 1997 Effects of metformin on insulin secretion, insulin action, and ovarian steroidogenesis in women with polycystic ovary syndrome 1. Journal of Clinical Endocrinology and Metabolism 82 524-530. (https://doi.org/10.1210/jcem.82.2.3722)

Faure M, Guibert E, Alves S, Pain B, Ramé C, Dupont J, Brillard JP \& ent P 2016 The insulin sensitiser metformin regulates chicken Sertoli and germ cell populations. Reproduction 151 527-538. (https://doi.org/10.1530/ REP-15-0565) 
Foretz M, Hébrard S, Leclerc J, Zarrinpashneh E, Soty M, Mithieux G, Sakamoto K, Andreelli F \& Viollet B 2010 Metformin inhibits hepatic gluconeogenesis in mice independently of the LKB1/AMPK pathway via a decrease in hepatic energy state. Journal of Clinical Investigation $\mathbf{1 2 0}$ 2355-2369. (https://doi.org/10.1172/JCl40671)

Fukuda S, Orisaka M, Tajima K, Hattori K \& Kotsuji F 2009 Luteinizing hormone-induced Akt phosphorylation and androgen production are modulated by MAP kinase in bovine theca cells. Journal of Ovarian Research 2 17. (https://doi.org/10.1186/1757-2215-2-17)

Fullerton MD, Galic S, Marcinko K, Sikkema S, Pulinilkunnil T, Chen ZP, O'Neill HM, Ford RJ, Palanivel R, O'Brien M et al. 2013 Single phosphorylation sites in Acc1 and Acc2 regulate lipid homeostasis and the insulin-sensitizing effects of metformin. Nature Medicine 19 1649-1654. (https://doi.org/10.1038/nm.3372)

Ghanem K \& Johnson AL 2019 Response of hen pre-recruitment ovarian follicles to follicle stimulating hormone, in vivo. General and Comparative Endocrinology 270 41-47. (https://doi.org/10.1016/j. ygcen.2018.10.004)

Hendricks III GL, Hadley JA, Krzysik-Walker SM, Prabhu KS, VasilatosYounken R \& Ramachandran R 2009 Unique profile of chicken adiponectin, a predominantly heavy molecular weight multimer, and relationship to visceral adiposity. Endocrinology $\mathbf{1 5 0} 3092-3100$. (https://doi.org/10.1210/en.2008-1558)

Hughes CHK, Bosviel R, Newman JW \& Pate JL 2019 Luteal lipids regulate progesterone production and may modulate immune cell function during the estrous cycle and pregnancy. Frontiers in Endocrinology 10 662. (https://doi.org/10.3389/fendo.2019.00662)

Johnson AL 2015 Ovarian follicle selection and granulosa cell differentiation. Poultry Science 94 781-785. (https://doi.org/10.3382/ps/peu008)

Johnson AL \& Lee J 2016 Granulosa cell responsiveness to follicle stimulating hormone during early growth of hen ovarian follicles. Poultry Science 95 108-114. (https://doi.org/10.3382/ps/pev318)

Johnson AL, Bridgham JT \& Swenson JA 2001 Activation of the Akt/protein kinase B signaling pathway is associated with granulosa cell survival. Biology of Reproduction 64 1566-1574. (https://doi.org/10.1095/ biolreprod64.5.1566)

Kai Y, Kawano Y, Yamamoto H \& Narahara H 2015 A possible role for AMP-activated protein kinase activated by metformin and AICAR in human granulosa cells. Reproductive Biology and Endocrinology 1327. (https://doi.org/10.1186/s12958-015-0023-2)

Kalender A, Selvaraj A, Kim SY, Gulati P, Brûlé S, Viollet B, Kemp BE, Bardeesy N, Dennis P, Schlager J et al. 2010 Metformin, independent of AMPK, inhibits mTORC1 in a rag GTPase-dependent manner. Cell Metabolism 11 390-401. (https://doi.org/10.1016/j.cmet.2010.03.014)

Kim D \& Johnson AL 2018 Differentiation of the granulosa layer from hen prehierarchal follicles associated with follicle-stimulating hormone receptor signaling. Molecular Reproduction and Development 85 729-737. (https://doi.org/10.1002/mrd.23042)

Kim JH, Lee KJ, Seo Y, Kwon JH, Yoon JP, Kang JY, Lee HJ, Park SJ, Hong SP, Cheon JH et al. 2018 Effects of metformin on colorectal cancer stem cells depend on alterations in glutamine metabolism. Scientific Reports 8 409. (https://doi.org/10.1038/s41598-017-18762-4)

Krzysik-Walker SM, Ocón-Grove OM, Maddineni SB, Hendricks GL \& Ramachandran R 2007 Identification of calcitonin expression in the chicken ovary: influence of follicular maturation and ovarian steroids. Biology of Reproduction 77 626-635. (https://doi.org/10.1095/ biolreprod.106.054957)

Lefloch R, Pouysségur J \& Lenormand P 2008 Single and combined silencing of ERK1 and ERK2 reveals their positive contribution to growth signaling depending on their expression levels. Molecular and Cellular Biology 28 511-527. (https://doi.org/10.1128/MCB.00800-07)

Livak KJ \& Schmittgen TD 2001 Analysis of relative gene expression data using real-time quantitative PCR and the $2-\triangle \triangle C T$ method. Methods 25 402-408. (https://doi.org/10.1006/meth.2001.1262)

Maddineni S, Metzger S, Ocón O, Hendricks G \& Ramachandran R 2005 Adiponectin gene is expressed in multiple tissues in the chicken: food deprivation influences adiponectin messenger ribonucleic acid expression. Endocrinology 146 4250-4256. (https://doi.org/10.1210/ en.2005-0254)

Maddineni SR, Ocón-Grove OM, Krzysik-Walker SM, Hendricks GL \& Ramachandran R 2008 Gonadotropin-inhibitory hormone (GnIH) receptor gene is expressed in the chicken ovary: potential role of
GnlH in follicular maturation. Reproduction 135 267-274. (https://doi. org/10.1530/REP-07-0369)

Mansfield R, Galea R, Brincat M, Hole D \& Mason H 2003 Metformin has direct effects on human ovarian steroidogenesis. Fertility and Sterility $\mathbf{7 9}$ 956-962. (https://doi.org/10.1016/s0015-0282(02)04925-7)

Miller RA, Chu Q, Xie J, Foretz M, Viollet B \& Birnbaum MJ 2013 Biguanides suppress hepatic glucagon signalling by decreasing production of cyclic AMP. Nature 494 256-260. (https://doi.org/10.1038/nature11808)

Morin-Papunen LC, Koivunen RM, Ruokonen A \& Martikainen HK 1998 Metformin therapy improves the menstrual pattern with minimal endocrine and metabolic effects in women with polycystic ovary syndrome. Fertility and Sterility 69 691-696. (https://doi.org/10.1016/ s0015-0282(98)00011-9)

Owen MR, Doran E \& Halestrap AP 2000 Evidence that metformin exerts its anti-diabetic effects through inhibition of complex 1 of the mitochondrial respiratory chain. Biochemical Journal 348 607-614. (https://doi.org/10.1042/bj3480607)

Pan YE, Liu ZC, Chang CJ, Xie YL, Chen CY, Chen CF, Walzem RL \& Chen SE 2012 Ceramide accumulation and up-regulation of proinflammatory interleukin-1beta exemplify lipotoxicity to mediate declines of reproductive efficacy of broiler hens. Domestic Animal Endocrinology 42 183-194. (https://doi.org/10.1016/j.domaniend.2011.12.001)

Pasquali R \& Casimirri F 1993 The impact of obesity on hyperandrogenism and polycystic ovary syndrome in premenopausal women. Clinical Endocrinology 39 1-16. (https://doi.org/10.1111/j.1365-2265.1993. tb01744.x)

Pasquali R, Pelusi C, Genghini S, Cacciari M \& Gambineri A 2003 Obesity and reproductive disorders in women. Human Reproduction Update $\mathbf{9}$ 359-372. (https://doi.org/10.1093/humupd/dmg024)

Perriello G, Misericordia P, Volpi E, Santucci A, Santucci C, Ferrannini E, Ventura MM, Santeusanio F, Brunetti P \& Bolli GB 1994 Acute antihyperglycemic mechanisms of metformin in NIDDM: evidence for suppression of lipid oxidation and hepatic glucose production. Diabetes 43 920-928.

Petroff MG, Mark Coggeshall KM, Jones LS \& Pate JL 1997 Bovine luteal cells elicit major histocompatibility complex class II-dependent T-cell proliferation. Biology of Reproduction 57 887-893. (https://doi. org/10.1095/biolreprod57.4.887)

Prager R, Schernthaner G \& Graf H 1986 Effect of metformin on peripheral insulin sensitivity in non insulin dependent diabetes mellitus. Diabete and Metabolisme 12 346-350. (available at: http://www.ncbi.nlm.nih.g ov/pubmed/3817257)

Ramachandran R, Ocón-Grove OM \& Metzger SL 2007 Molecular cloning and tissue expression of chicken AdipoR1 and AdipoR2 complementary deoxyribonucleic acids. Domestic Animal Endocrinology 33 19-31. (https://doi.org/10.1016/j.domaniend.2006.04.004)

Rice S, Pellatt L, Ramanathan K, Whitehead SA \& Mason HD 2009 Metformin inhibits aromatase via an extracellular signal-regulated kinase-mediated pathway. Endocrinology 150 4794-4801. (https://doi. org/10.1210/en.2009-0540)

Sato T, Toyoshima A, Hiraki T, Ohta Y, Katayama K, Arai T \& Tazaki H 2011 Effects of metformin on plasma concentrations of glucose and mannose, G6Pase and PEPCK activity, and mRNA expression in the liver and kidney of chickens. British Poultry Science 52 273-277. (https://doi. org/10.1080/00071668.2011.560595)

Tajima K, Dantes A, Yao Z, Sorokina K, Kotsuji F, Seger R \& Amsterdam A 2003 Down-regulation of steroidogenic response to gonadotropins in human and rat preovulatory granulosa cells involves mitogen-activated protein kinase activation and modulation of DAX-1 and steroidogenic factor-1. Journal of Clinical Endocrinology and Metabolism 88 2288-2299. (https://doi.org/10.1210/jc.2002-020913)

Tajima K, Yoshii K, Fukuda S, Orisaka M, Miyamoto K, Amsterdam A \& Kotsuji F 2005 Luteinizing hormone-induced extracellular-signal regulated kinase activation differently modulates progesterone and androstenedione production in bovine theca cells. Endocrinology 146 2903-2910. (https://doi.org/10.1210/en.2005-0093)

Tang T, Glanville J, Orsi N, Barth JH \& Balen AH 2006 The use of metformin for women with PCOS undergoing IVF treatment. Human Reproduction 21 1416-1425. (https://doi.org/10.1093/humrep/del025)

Tilly JL \& Johnson AL 1987 Presence and hormonal control of plasminogen activator in granulosa cells of the domestic hen. Biology of Reproduction 37 1156-1164. (https://doi.org/10.1095/biolreprod37.5.1156) 
Tilly JL, Kowalski KI \& Johnson AL 1991 Stage of Ovarian Follicular Development Associated with the Initiation of Steroidogenic Competence in Avian Granulosa Cells1. Biology of Reproduction 44 305-314. (https://doi.org/10.1095/biolreprod44.2.305)

Tosca L, Froment P, Solnais P, Ferré P, Foufelle F \& Dupont J 2005 Adenosine 5'-monophosphate-activated protein kinase regulates progesterone secretion in rat granulosa cells. Endocrinology 146 4500-4513. (https:// doi.org/10.1210/en.2005-0301)

Tosca L, Crochet S, Ferre P, Foufelle F, Tesseraud S \& Dupont J 2006 AMPactivated protein kinase activation modulates progesterone secretion in granulosa cells from hen preovulatory follicles. Journal of Endocrinology 190 85-97. (https://doi.org/10.1677/joe.1.06828)

Tosca L, Chabrolle C, Uzbekova S \& Dupont J 2007 Effects of metformin on bovine granulosa cells steroidogenesis: possible involvement of adenosine $5^{\prime}$ monophosphate-activated protein kinase (AMPK). Biology of Reproduction 76 368-378. (https://doi.org/10.1095/ biolreprod.106.055749)

Tosca L, Ramé C, Chabrolle C, Tesseraud S \& Dupont J 2010 Metformin decreases IGF1-induced cell proliferation and protein synthesis through AMP-activated protein kinase in cultured bovine granulosa cells. Reproduction 139 409-418. (https://doi.org/10.1530/REP-09-0351)

Tosca L, Solnais P, Ferré P, Foufelle F, Dupont J, Ferre P $2006 b$ Metformininduced stimulation of adenosine $5^{\prime}$ monophosphate-activated protein kinase (PRKA) impairs progesterone secretion in rat granulosa cells. Biology of Reproduction 75 342-351. (https://doi.org/10.1095/ biolreprod.106.050831)

van Santbrink EJP, Hohmann FP, Eijkemans MJC, Laven JSE \& Fauser BCJM 2005 Does metformin modify ovarian responsiveness during exogenous FSH ovulation induction in normogonadotrophic anovulation? A placebo-controlled double-blind assessment. European Journal of Endocrinology 152 611-617. (https://doi.org/10.1530/eje.1.01866)

Vandermolen DT, Ratts VS, Evans WS, Stovall DW, Kauma SW \& Nestler JE 2001 Metformin increases the ovulatory rate and pregnancy rate from clomiphene citrate in patients with polycystic ovary syndrome who are resistant to clomiphene citrate alone. Fertility and Sterility 75 310-315. (https://doi.org/10.1016/s0015-0282(00)01675-7)

Velazquez E, Acosta A \& Mendoza SG 1997 Menstrual cyclicity after metformin therapy in polycystic ovary syndrome. Obstetrics and Gynecology $90 \quad 392-395 . \quad$ (https://doi.org/10.1016/s00297844(97)00296-2)

Vrbikova J, Hill M, Starka L, Cibula D, Bendlova B, Vondra K, Sulcova J \& Snajderova M 2001 The effects of long-term metformin treatment on adrenal and ovarian steroidogenesis in women with polycystic ovary syndrome. European Journal of Endocrinology 144 619-628. (https:// doi.org/10.1530/eje.0.1440619)

Walzem RL \& Chen SE 2014 Obesity-induced dysfunctions in female reproduction: lessons from birds and mammals. Advances in Nutrition $\mathbf{5}$ 199-206. (https://doi.org/10.3945/an.113.004747)

Westfall SD, Hendry IR, Obholz KL, Rueda BR \& Davis JS 2000 Putative role of the phosphatidylinositol 3-kinase-Akt signaling pathway in the survival of granulosa cells Endocrine 12 315-321. (https://doi. org/10.1385/ENDO:12:3:315)

Woods DC \& Johnson AL 2005 Regulation of follicle-stimulating hormonereceptor messenger RNA in hen granulosa cells relative to follicle selection. Biology of Reproduction 72 643-650. (https://doi.org/10.1095/ biolreprod.104.033902)

Wu X, Yeerna H, Goto Y, Ando T, Wu VH, Zhang X, Wang Z, Amornphimoltham P, Murphy AN, Tamayo P et al. 2019 Metformin inhibits progression of head and neck squamous cell carcinoma by acting directly on carcinoma-initiating cells. Cancer Research 79 4360-4370. (https://doi.org/10.1158/0008-5472.CAN-18-3525)

Yu MW, Robinson FE, Charles RG \& Weingardt R 1992a Effect of feed allowance during rearing and breeding on female broiler breeders. 2 . Ovarian morphology and production. Poultry Science 71 1750-1761. (https://doi.org/10.3382/ps.0711750)

Yu MW, Robinson FE \& Etches RJ 1992b Effect of feed allowance during rearing and breeding on female broiler breeders. 3. Ovarian steroidogenesis. Poultry Science 71 1762-1767. (https://doi.org/10.3382/ ps.0711762)

Zhou P, Baumgarten SC, Wu Y, Bennett J, Winston N, Hirshfeld-Cytron J \& Stocco C 2013 IGF-I signaling is essential for FSH stimulation of AKT and steroidogenic genes in granulosa cells. Molecular Endocrinology 27 511-523. (https://doi.org/10.1210/me.2012-1307)

Zhou X, Kuang Y, Liang S \& Wang L 2019 Metformin inhibits cell proliferation in SKM-1 cells via AMPK-mediated cell cycle arrest. Journal of Pharmacological Sciences 141 146-152. (https://doi.org/10.1016/j. jphs.2019.10.003)

Received 4 February 2020

First decision 9 March 2020

Revised manuscript received 25 June 2020

Accepted 3 August 2020 